\title{
Resumption of studies on pollen deposition in the III Campus of the Jagiellonian University in Krakow
}

\author{
Joanna Bokalska-Rajba ${ }^{1,2}$, Dorota Nalepka² \\ ${ }^{1}$ Doctoral Studies in Natural Sciences at the Polish Academy of Sciences in Kraków, 31-512 Kraków, Lubicz 46 \\ ${ }^{2}$ W. Szafer Institute of Botany, Polish Academy of Sciences, 31-512 Kraków, Lubicz 46 \\ e-mail: boasia@poczta.onet.pl, D.Nalepka@botany.pl
}

Received: 22 April 2017/Accepted: 30 May 2017

\begin{abstract}
Collected in 2016 samples from the surface and from the soil profiles, contained enough amounts of sporomorphs to have started studies on pollen deposition near the III Campus of the Jagiellonian University in Krakow. Preliminary results of the first year of research are presented (percentage pollen diagram and pollen accumulation rate) and compared with chosen results from previous years of research.
\end{abstract}

Keywords: pollen percentages, pollen accumulation rates, surface and soil samples, Krakow vicinity

\section{Introduction}

Research on pollen rain, which was conducted in 20062009 years, near the III Jagiellonian University Campus in Krakow (Fig. 1), was resumed in 2016. In October 2016, at the same nine sites as before, soil samples were collected, and Tauber-type traps were placed (Hicks et al. 1996; Pidek et al. 2010). Moreover, expanding the scope of the study, nine soil profiles have been collected. Samples were collected from open and wooded stands from the communities described in detail by E. Dubiel (Dubiel 2005).

The main goal of the undertaken study is to determine to what extent pollen rain reflects local and regional vegetation based on a comparison of the annual pollen rain collected in Tauber-type traps with pollen content in soil samples located in different plant communities.

The purpose of the first phase of research, started in 2016 , is to compare the sporomorphs content in surface soil samples and selected soil levels.

\section{Study area}

Sites numbered 1, 3 and 5 are located in the open landscape. Sites numbered 1 and 3 there are meadows, partially transformed by the man, and site numbered 5 there is the xerothermic grassland. Site numbered 2, 4 and 6 are located in the artificial wooded stands; in the riparian forests (sites 2, and 4) and in the hornbeam-oak forest (Fig. 1).

\section{Material and methods}

Samples, with a volume of $1 \mathrm{~cm}^{3}$, were taken from the $5 \mathrm{~cm}^{2}$ surface of the soil (Fig. 2a), and samples, with a volume of $1 \mathrm{~cm}^{3}$, were taken from a depth of $1-2 \mathrm{~cm}$, and $5-6 \mathrm{~cm}$ of the soil profile (Fig. 2b). Samples were prepared using standard laboratory procedures (Faegri et al. 1989). Tablets containing indicator (Lycopodium spores) were added to calculate the sporomorphs concentration (Stockmarr 1971). So far, sporomorphs have been calculated on the surface of a single microscope slide $(24 \times 24 \mathrm{~mm})$. 


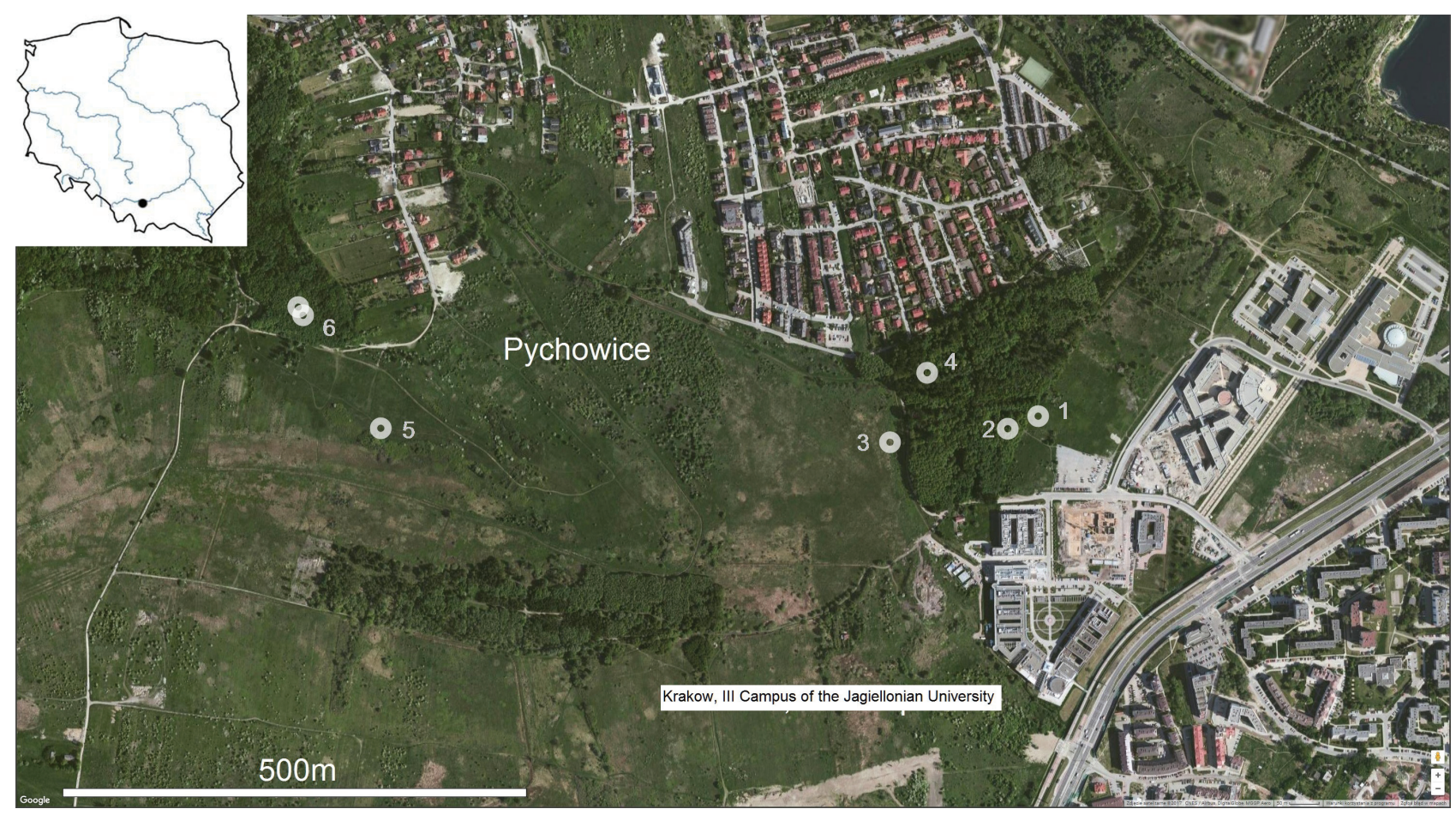

Figure 1. Location of the investigated sites, numbered 1-6, in the vicinity of Jagiellonian University Campus III; satellite photo (Google Earth)

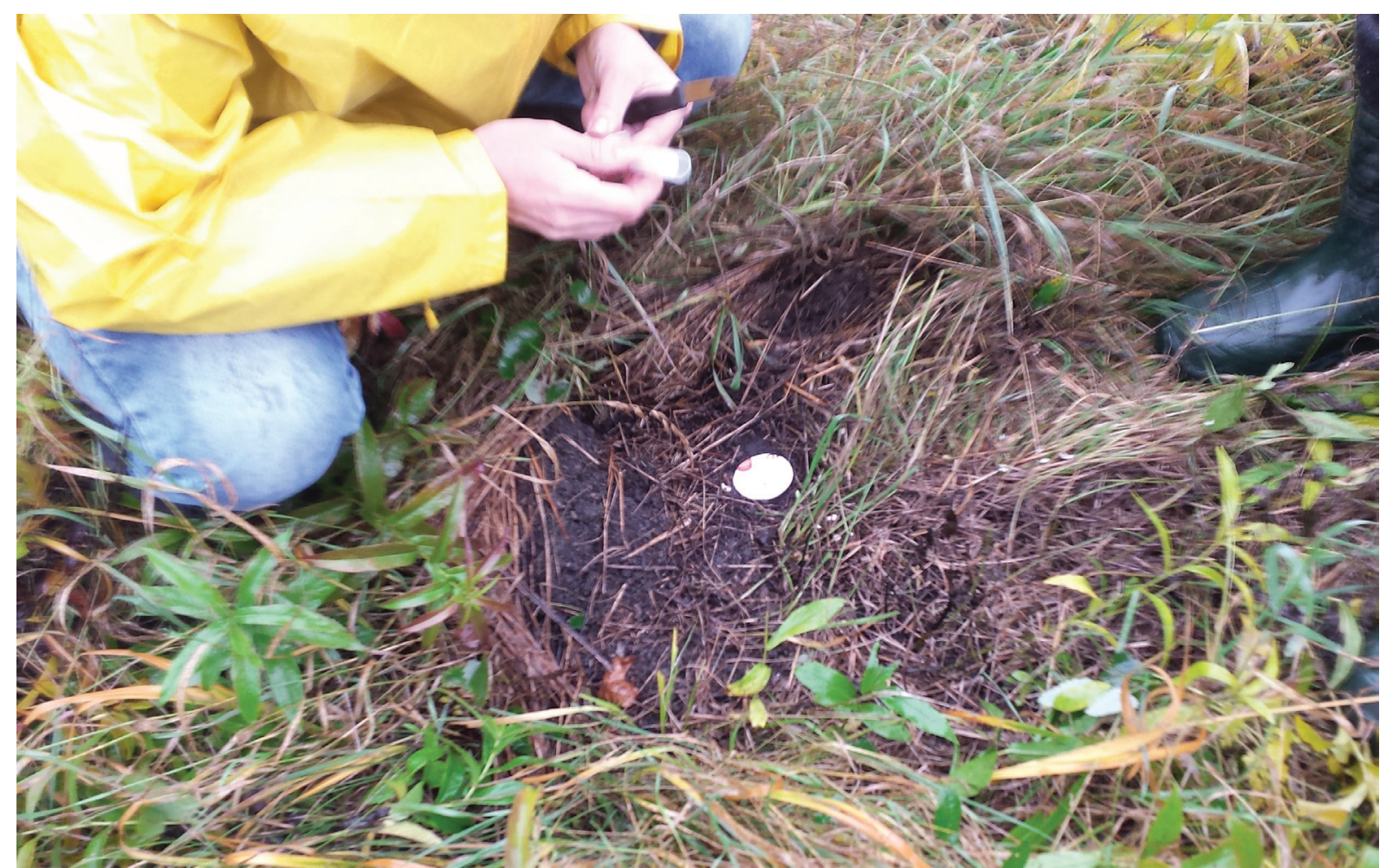

Figure 2a. Sampling for palynological studies from the surface of the soil; Photo D. Nalepka 


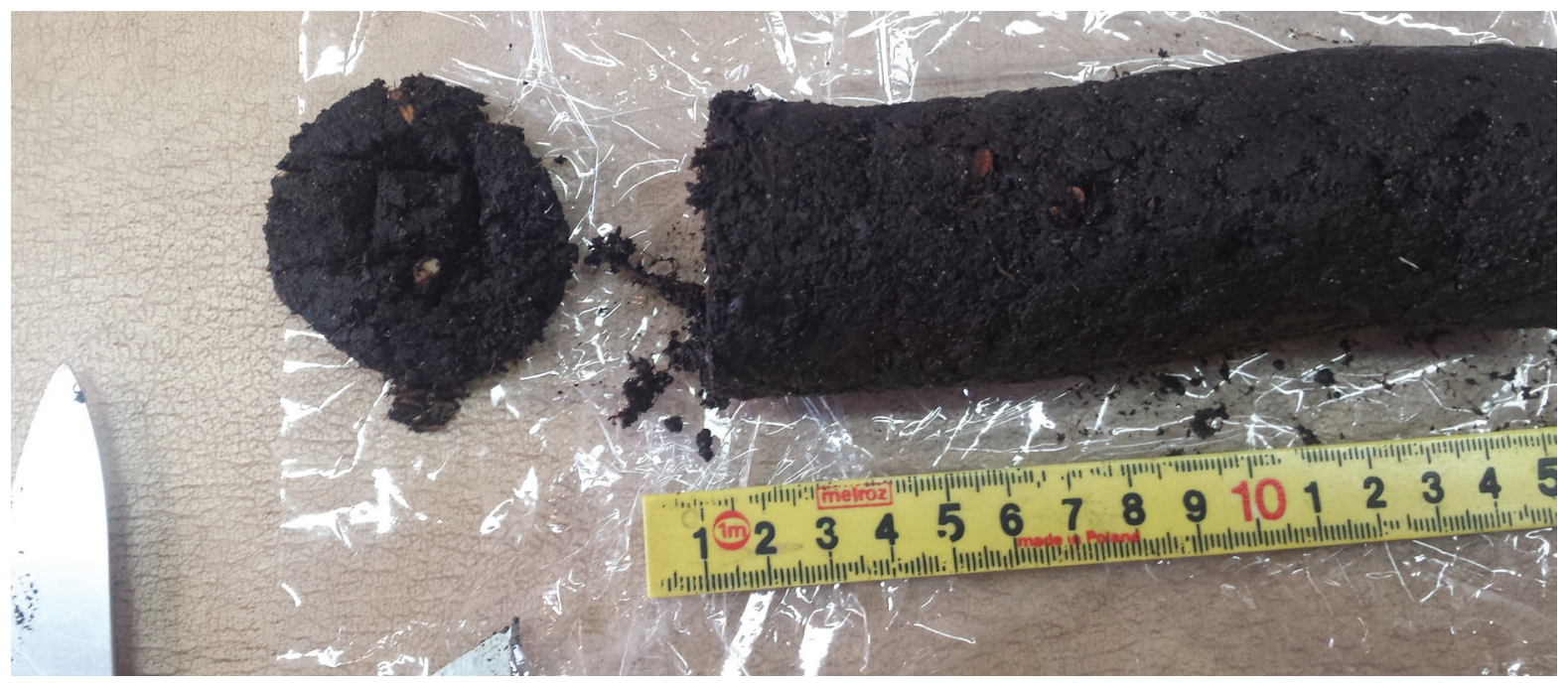

Figure 2b. Sampling for palynological studies: from the soil profile; Photo D. Nalepka

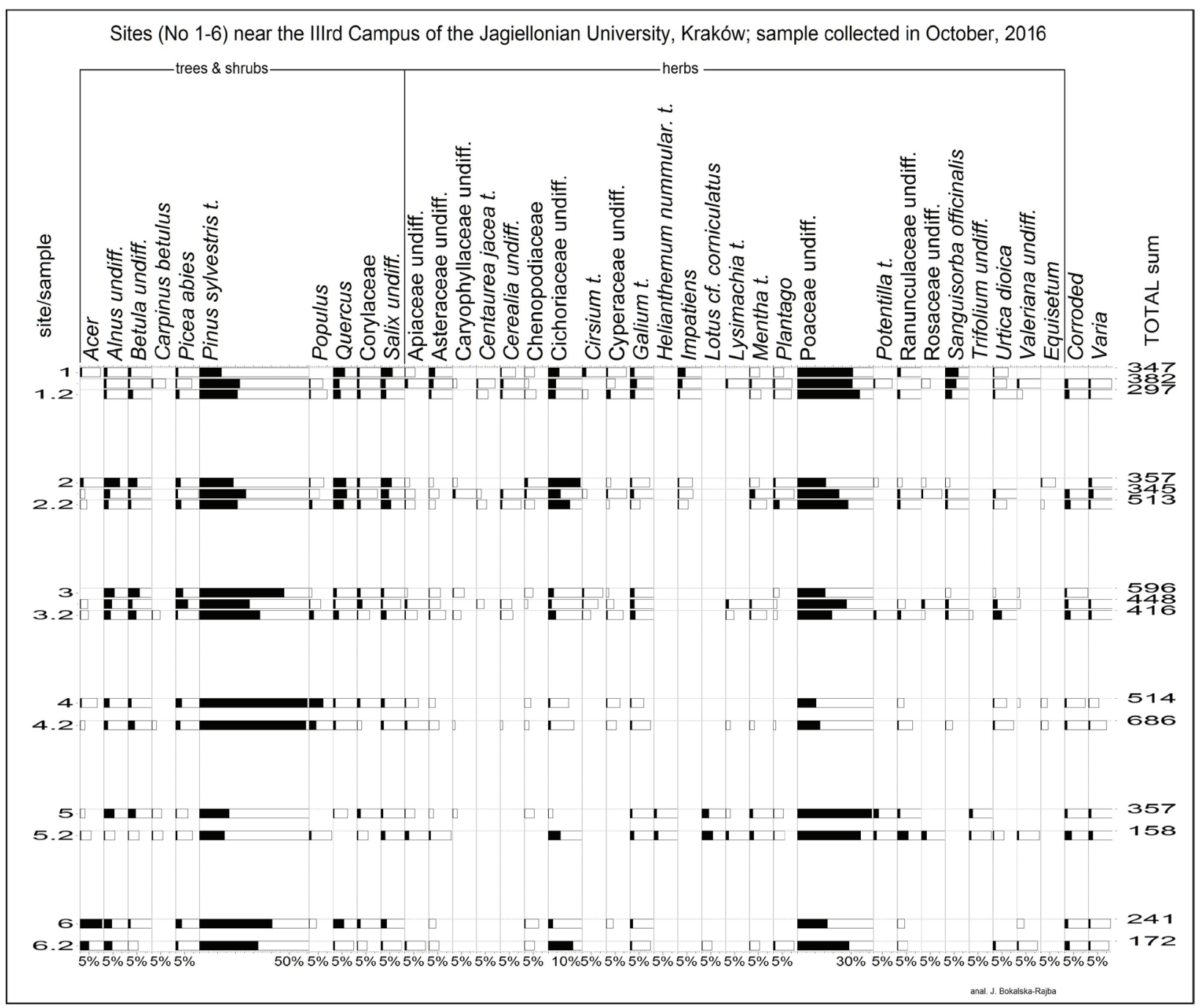

Figure 3. Percentage pollen diagram of selected taxa present in surface soil samples and deeper levels $(5-7 \mathrm{~cm})$ from sites $1-6$ 
Results are graphically presented in the POLPAL pollen diagram convention (Nalepka \& Walanus 2003). Sample numbers (integers) correspond to site numbers and represent a surface samples. Decimal numbers correspond to sample numbers from subsequent depths in soil profiles.

In all, till now analysed samples, the most contemporary ones taken from the surface of the soil as well as in the lower depths sporomorphs are present (Fig. 3).

Until now, samples from sites numbered 1-6 have been analysed. These numbered as 1-3 there are samples from the surface, samples from $0-1 \mathrm{~cm}$ depth and samples from depths of 5-6 cm. These numbered as 4-6 there are samples from the surface, and from depths of 5-6 cm. Pollen Accumulation Rate (PAR) was counted for selected taxa from soil surface samples and for Tauber-type traps.

\section{Results and discussions}

Presently, the results of the previous years' study with the first three analysed sites were summarized (Table 1).

Pollen spectra from sites numbered 1 and 2 contain a slightly higher percentage of Quercus grains; there are oaks growing around these stands (Fig. 4).
Pollen spectra from site numbered 3 contain a higher percentage of pollen grains of trees and shrubs, although they are located in an open area.

Pollen spectra from site numbered 4 contain the highest percentage of Pinus sylvestris and Populus pollen is comparison to other sites. The poplar grows at this position.

Pollen spectra from site numbered 5 are the richest in respect of taxonomic composition. The stand is located on an open slope, in xerothermic grassland.

Pollen spectra from site numbered 6 are the poorest, and the least varied in terms of the taxonomic composition. There is a greater amount of Acer pollen grains from the maple trees that grow in this place.

Pollen spectra from the surface, and the depth samples from the site numbered $1-4$, show little difference in terms of taxonomy composition and very small in terms of their percentage. Based on the first results of the study, started in 2017, it can be stated that the percentage of pollen grains of herbaceous plants in the majority of examined sites is greater in depth than in surface samples. Pollen spectra from the depth are more varied, richer in terms of taxonomic composition, from sites numbered 1, 3, 4 and 6 .

Table 1. Pollen Accumulation Rate for selected sites and for selected taxa for the years 2006, 2008, 2009 and 2016

\begin{tabular}{|c|c|c|c|c|c|c|c|c|}
\hline \multirow{2}{*}{$\begin{array}{c}\text { Sites } \\
\text { number }\end{array}$} & \multirow{2}{*}{ Sample type } & \multicolumn{7}{|c|}{ Pollen accumulation rate for selected taxa } \\
\hline & & Pinus & Picea & Alnus & Salix & Quercus & Betula & year \\
\hline \multirow{5}{*}{1} & Soil sample1 & 6640 & 620 & 600 & 560 & 680 & 700 & 2006 \\
\hline & $\begin{array}{c}\text { Tauber - type } \\
\text { trap } 1\end{array}$ & 4243 & 324,3 & 12081 & 3054 & 11162 & 17378 & 2008 \\
\hline & Soil sample 2 & 4000 & 333,3 & 410 & 141 & 397,5 & 782 & 2009 \\
\hline & $\begin{array}{c}\text { Tauber - type } \\
\text { trap } 2\end{array}$ & 540 & 51,7 & 373,5 & 655 & 540 & 683 & 2009 \\
\hline & Soil sample 3 & 3415,1 & 397 & 555 & 1827 & 1827 & 555 & 2016 \\
\hline \multirow{3}{*}{2} & Soil sample 1 & 2882 & 400 & 538 & 772 & 842 & 1034 & 2006 \\
\hline & $\begin{array}{c}\text { Tauber - type } \\
\text { trap } 1\end{array}$ & 12040 & 979,5 & 10449 & 3142,8 & 4857 & 21632 & 2008 \\
\hline & Soil sample 3 & 6371 & 937 & 2998 & 2061 & 2436 & 1780 & 2016 \\
\hline \multirow{5}{*}{3} & Soil sample 1 & 7476 & 691,5 & 335 & 149,5 & 93,5 & 1102 & 2006 \\
\hline & $\begin{array}{c}\text { Tauber - type } \\
\text { trap } 1\end{array}$ & 14737 & 421 & 11578 & 1157,9 & 842 & 18526 & 2008 \\
\hline & Soil sample 2 & 28780,5 & 2244 & 1707 & 243,9 & 195 & 6487 & 2009 \\
\hline & $\begin{array}{c}\text { Tauber - type } \\
\operatorname{trap} 2\end{array}$ & 2605,3 & 214,5 & 245 & 590 & 413,7 & 590 & 2009 \\
\hline & Soil sample 3 & 12688 & 1143 & 1614 & 493 & 583 & 1793 & 2016 \\
\hline
\end{tabular}




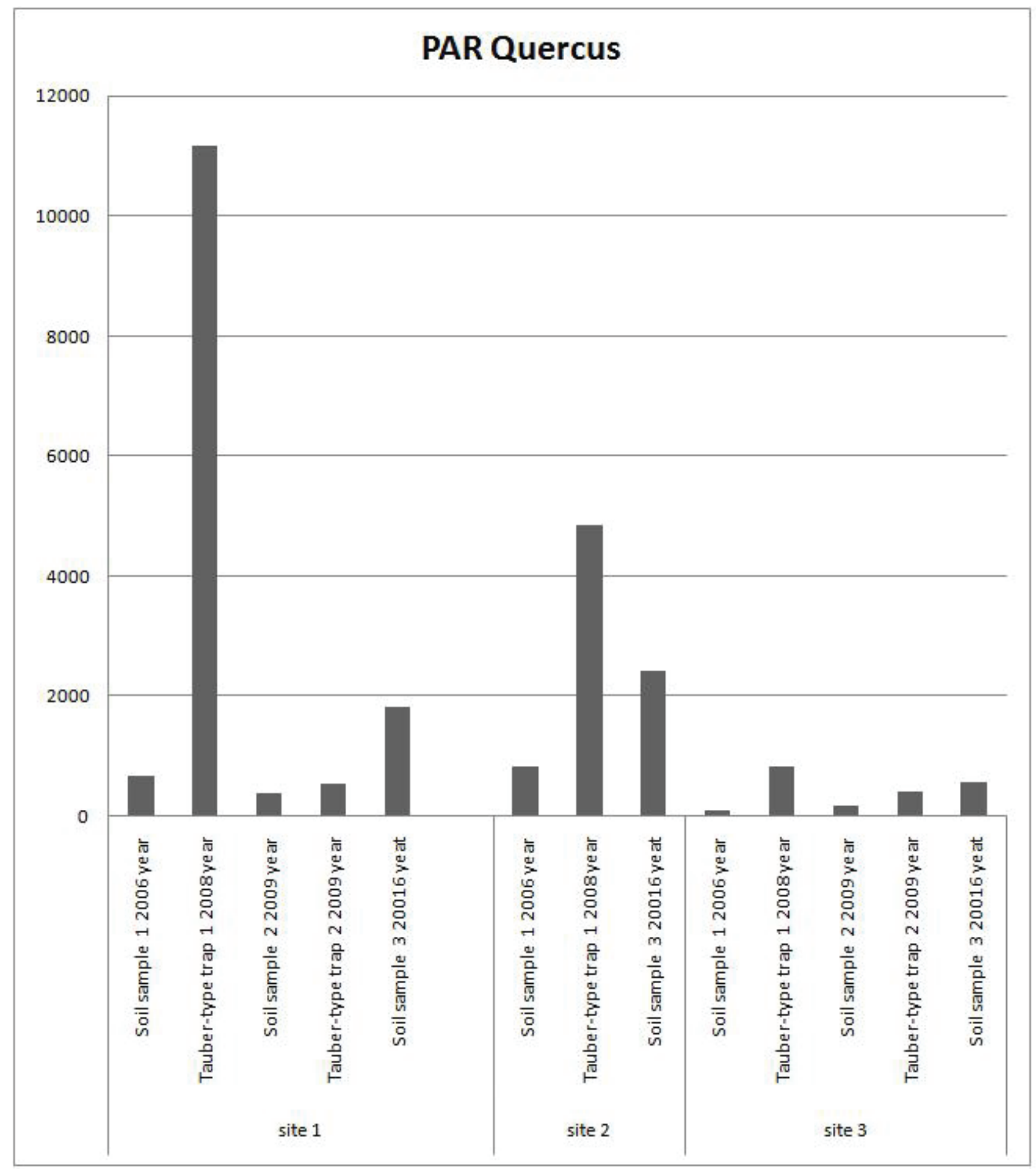

Figure 4. Pollen Accumulation Rate for Quercus in Soil sample 1, Tauber-type trap 1, Soil sample 2, and Soil sample 3 for the years 2006-2009 and 2016 


\section{Conclusions}

Fluctuations in the sums of annual accumulation rate of particular taxa may be significant. The pollen content in the soil could be more erroneous. The pollen counts for traps, in relation to pollen content calculated from soil samples, show considerable differences, although not for all taxa (e. g. Pinus - larger differences, Quercus- lower differences).

\section{Acknowledgements}

The study was partly financed by the Statutory Research of W. Szafer Institute of Botany Polish Academy of Sciences.

\section{References}

Dubiel E., 2005, Mapa zbiorowisk roślinnych III Kampusu Uniwerstytetu Jagiellońskiego i okolic, Instytut Botaniki Uniwersytetu Jagiellońskiego, Kraków.
Faegri K., Kaland P.E. \& Krzywinski K., 1989, Textbook of pollen analysis, IV. ed. Wiley \& Sons Ltd, Chichester-Singapore.

Hicks S., Ammann B., Latałowa M., Pardoe H. \& Tinsley H., 1996, European Pollen Monitoring Programme. Project Description and Guidelines, Oulu University Press, Oulu, Finland.

Nalepka D. \& Walanus A., 2003, Data processing in pollen analysis, Acta Palaeobotanica 43: 125-134.

Pidek I.A., Svitavská-Svobodová H., van der Knaap W.O., Noryśkiewicz A.M., Filbrandt-Czaja A., Noryśkiewicz B., Latałowa M., Zimny M., Święta-Musznicka J., Bozilova E., Tonkov S., Filipova-Marinova M., Poska A., Giesecke T., \& Gikov, A., 2010, Variation in annual pollen accumulation rates of Fagus along a N-S transect in Europe based on pollen traps, Vegetation History and Archaeobotany 19: 259-270. doi:10.1007/ s00334-010-0248-0

Stockmarr J., 1971, Tablets with spores used in absolute pollen analysis, Pollen et Spores 13: 615-621. 